\title{
LA UNIVERSIDAD DE CHILE, LA BIBLIOTECA NACIONAL Y EL LIBRO
}

\author{
Gabriel Amunátegui \\ Director de la Biblioteca Nacional (1937)
}

Desde hace algunos días la prensa registra en sus columnas, entre informaciones referentes a la horrible tragedia que sacude a España y atormenta al mundo, a las agitaciones políticas precursoras de nuestro proceso electoral de Marzo, a las actividades de orden económico —contribuyentes que reclaman impuestos que reputan gravosos, empleados y obreros que reivindican mejor remuneración-, la noticia de que la Universidad de Chile celebra la «Primera Exposición del Libro Americano y Español».

Feliz concepción la de esta idea, cuya realización significa para la casa de Bello un acertado negocio moral.

En esta hora inquieta y angustiada, de intensa atracción hacia lo material, de inclinación reverente al becerro de oro, la Universidad de Chile conmemora el aniversario de su fundación con un torneo intelectual, con una fiesta del espíritu, en que rinde homenaje a su majestad el libro.

Universidades, Bibliotecas y organismos culturales de España, Estados Unidos de Norte América y los países iberoamericanos, así como nuestras casas editoriales, han enviado ejemplares de sus impresos, y, en torno de la exposición que de ellos se hace en los grandes patios de este viejo y hospitalario caserón, se desarrolla un programa de conferencias que subrayan algunos tópicos de interés concernientes al libro y al escritor.

Feliz concepción la de esta idea, repito, señores, porque soy de los que sienten que es preciso modificar los rumbos que sigue la humanidad, devolviendo a la inteligencia sus fueros y reclamando para ella la consideración y el respeto a que es acreedora.

Como lo anotara en uno de sus magistrales discursos don Juan Agustín Barriga, «-ni Bello ni Portales debieron nada a la fortuna que muchas veces les fué contraria, y sin embargo ¿quién no se inclina respetuoso y lleno de gratitud ante sus sombras venerandas? Volvamos a la senda que ellos trazaron y que nosotros hemos perdido por un falso concepto de la jerarquía humana, fundado en valores que no resisten al análisis y que a veces basta para disipar el más ligero contraste de la fortuna adversa—».

La Biblioteca Nacional, cuya cuna arranca de los seculares anaqueles de la colonial Universidad de San Felipe y cuyos orígenes se enlazan con los de esta casa, al asociarse a este acontecimiento exteriorizará, por medio de su personero, algunos breves y sencillos conceptos fundamentales.

«La Universidad de Chile, la Biblioteca Nacional y el libro» es el epígrafe de estas líneas. Universidad y Biblioteca, órganos complementarios, cuya función armónica en el conglomerado social determina dotar al hombre de la capacidad para aprender y de los medios conducentes a satisfacerla. 
Escuela, Liceo, Universidad — la escala correlacionada y ascendente de la enseñanza sistemática-, no obran tanto sobre el individuo comunicando conocimientos, como inculcando el deseo de saber. Y es la Biblioteca Pública el órgano que debe proporcionar la oportunidad de satisfacer ese anhelo de educación y cultura.

La Universidad, a través de sus distintas Escuelas, imparte por medio de sus catedráticos las nociones fundamentales de las diversas disciplinas científicas, literarias, artísticas.

Y la ampliación de esos conocimientos y su ahondamiento se realizan, como una función de Seminario, de un Seminario donde la propia iniciativa puede también ejercerse libremente, en la Biblioteca Pública, donde el estudioso deberá encontrar todo el valioso material bibliográfico que el maestro le haya señalado en su clase de la víspera.

Universidad y Biblioteca, al servir distintas etapas del complejo proceso educacional, deben mantener una estrecha y armónica coordinación. Así, por ejemplo, debe existir una perfecta correlación entre la Biblioteca Nacional —-tipo de biblioteca general que participa de los caracteres de la vulgarización y de la especialización-, con las bibliotecas particulares o especiales de las distintas Escuelas Universitarias, sobre la base, en primer término, de un Catálogo Central.

Mas, es preciso que esa armonía y correlación no lleguen a identificar el servicio de esa doble función — la de la Universidad y la de la Biblioteca- en un solo órgano.

La función de la Biblioteca Pública debe ser servida por su órgano propio, pues, señores, lejano está el tiempo en que la Biblioteca era una simple colección de libros, un panteón al cual solo acudía de cuando en vez o con cierta regularidad periódica alguno de esos pintorescos personajes de reluciente traje y de calva relumbrosa, a quien el vulgo, con cierto dejo irónico, designaba como ratón de bibliotecas.

Como quedara de manifiesto en el último Congreso Internacional de Bibliotecarios, verificado hace un año en Madrid, la importancia siempre creciente de las bibliotecas ha creado la profesión de bibliotecario. El bibliotecario, a su amor por los libros, a su cultura general, debe agregar la posesión de conocimientos técnicos especiales.

«El profesor-bibliotecario — anota Gabriela Mistral, delegado de Chile en ese Congreso, en el informe que enviara a nuestro gobierno- tiene la tendencia a ver en la Biblioteca la prolongación de su clase y orienta a sus alumnos hacia lecturas especializadas. El bibliotecario profesional debe propender hacia la lectura amplia, libre, de universidad de conocimientos».

El bibliotecario debe procurar —agregaré—que la Biblioteca tenga una sensibilidad y eficacia más universales, rompiendo o ensanchando con gesto un poco revolucionario el angosto molde antiguo donde tantas generaciones han adquirido una fisonomía uniforme, pues la Biblioteca Pública debe ser un amplio instrumento de cultura.

El Instituto Internacional de Cooperación Intelectual, organismo de la Sociedad de las Naciones, realizó una encuesta en los más importantes países civilizados acerca del problema bibliotecario. Los informes producidos y que editara en un volumen bajo el título de Rol et formation du bibliothécaire, aparecido en 1935, revela que en casi todos ellos existen escuelas de bibliotecarios. La función social de la Biblioteca ha creado su órgano propio. 
Por nuestra parte, como una semilla que anhelamos ver fructificar, en el presente año se han desarrollado en nuestra Biblioteca Nacional, cursos de Biblioteconomía destinados al personal de esa repartición y de otras bibliotecas públicas. Con antelación, el Congreso Regional Pedagógico celebrado en la ciudad de Talca en 1933 había adoptado un acuerdo en ese sentido. Abrigo la esperanza de que esos cursos sean la célula generadora de la Escuela chilena de bibliotecarios.

Los Estados Unidos de Norte América, con su cabal concepción de una democracia —atestado elocuente es la reciente elección presidencial, en la que sufragó la casi totalidad de los inscritos_- ha comprendido que una de las palancas más poderosas de esa democracia, base de la grandeza norteamericana, es la Biblioteca Pública. Esa Biblioteca —como lo anota Nelson_ que comenzó siendo un anexo más o menos marginal en el plan nacional de instrucción pública y que se ha impuesto ya como uno de los instrumentos más eficaces de previsión social, pues la Biblioteca es hoy día la verdadera Universidad del Pueblo.

En esa nación, así como en los países europeos, está inculcado el convencimiento de que la Biblioteca es parte esencial de un sistema de educación. Un sistema educacional, se ha dicho, que sólo enseñase el arte de leer y que luego de desocupase de poner en las manos del pueblo la mejor lectura - precisamente cuando la mala literatura es tan barata y abundante-, sería inconveniente y absurdo. A propósito, puedo recordar que en una reunión promovida por un ex-Ministro de Educación que quería reemplazar medidas policíacas de represión de la lectura pornográfica por un procedimiento preventivo, hube de señalar mi modesto programa: «El mal libro se combate con el buen libro». Así, sencillamente, sin mayor pretensión. Enseñemos a nuestros niños y jóvenes, a nuestras clases proletarias, a leer bueno; eduquémosles el gusto y, a la vez —y esto es tan importante como el proceso educativo-, proporcionemos los medios materiales, los libros con qué satisfacer aquella necesidad. Formemos el hábito desde la infancia de la buena lectura y tengamos buenos libros. Con esas armas, adiós pornografía.

En este programa, sencillo y grande, la obra de la Biblioteca es fundamental y preventiva: se anticipa al mal, substituyéndolo por el antídoto, promueve el amor a lo que es bueno y noble, antes de que los bajos instintos tengan una oportunidad de envenenar el espíritu.

Hay todavía otra finalidad de las bibliotecas que es preciso consignar. La vida del hombre depende del uso que haya hecho de sus horas de ocio. La Biblioteca Pública es un agente de moralización, pues proporciona una sana actividad para todas las clases sociales durante los momentos que deja libres el trabajo cotidiano.

Permítanme, señores, después de este enunciado teórico, traer en espíritu hacia ustedes alguna de las posibilidades culturales que les ofrece nuestra Biblioteca, ya que se vio impedida, por circunstancias reglamentarias, para allegar a esta Exposición su aporte material. 
En la Biblioteca Nacional encontrará el lector — prescindiendo en estos instantes de su material de libros que procura, con sus exiguos recursos renovar incesantementeuna magnífica y completa colección de periódicos, desde aquel impreso que concibiera el fraile de la Buena Muerte hasta aquél que conserva aún fresca la tinta de sus máquinas, colección que con especial acierto ordenó recopilar mi distinguido antecesor don Alejandro Vicuña. Esos periódicos, hermanos del libro, tienen un valor inestimable, porque comprenden la historia más exacta y más viva de lo que la nación chilena ha sido y es desde sus orígenes. En ese enorme número de papeles han ido quedando estampadas día a día en letras de molde las ideas que han impulsado y las pasiones que han conmovido a nuestros abuelos, a nuestros padres y a nosotros mismos. Esa colección de todos los impresos nacionales conservada en la Biblioteca de Santiago compone una especie de memoria del pueblo chileno en que todo suceso, grande o pequeño, público o casero, ha dejado su huella. Esa gran colección es un cuadro fotográfico en que se ha ido reflejando la vida toda de nuestro país.

Hoy en día — y estimo interesante la cifra - el lector que acuda a la Biblioteca Nacional encontrará 551 diarios y periódicos que se editan actualmente en Chile, y 550 revistas nacionales. Es una cifra elocuente.

Aún hay más. Allá por 1885, don Miguel Luis Amunátegui en un editorial de El Mercurio sostenía la necesidad de que la Biblioteca tuviera una colección de revistas extranjeras. «Las revistas — decía el señor Amunátegui— contienen en el día el resumen del movimiento literario y científico del mundo civilizado. Quien las lee a menudo no puede menos de adquirir un gran acopio de conocimientos preciosos».

El pensamiento acariciado en 1885 es hoy día una realidad: la Biblioteca Nacional recibe actualmente, a título de subscripción, canje y donación, 216 revistas del continente americano y 191 europeas, y en la lista respectiva figura material literario, científico, artístico, técnico, etc.

Dentro de su mecanismo, la Biblioteca Nacional dirige la Comisión de la Biblioteca de Escritores de Chile, que ha sido puesta en marcha después de un receso de algunos años. Esa Comisión, que según mandato de ley debe consagrar exclusivamente sus volúmenes a los escritores chilenos fallecidos, editó el año último La Historia de la Administración Errázuriz por Isidoro Errázuriz, obra del más alto interés histórico y político; tiene ya en prensa una Antología poética que saldrá a la circulación en breve tiempo más y acordado un plan de trabajo para los años venideros. Ese plan comprende la publicación de antologías de cuentos y artículos periodísticos y obras de imaginación y científicas, etc.

Sensible es, y aprovecho la ocasión para exteriorizarlo, que la restricción de la ley impida a la Comisión extender su tarea hacia los escritores vivos y crear premios y certámenes que les sirvan de estímulo, en un país donde el talento y la pluma no tienen suficiente cotización. Abrigo la esperanza de que este torneo intelectual, entre otros frutos, patrocine la promulgación de una ley en tal sentido.

Debo todavía agregar que, convencida la Biblioteca Nacional de la verdad del adagio de que «el problema bibliotecario no es la colección de libros sino su circulación», o sea, que el libro debe ir hacia el lector, ha salido de su edificio esparciendo sus volúmenes a lo largo del territorio. En efecto, actualmente existe una sucursal de ella que funciona 
en el Liceo Barros Borgoño de esta ciudad, destinada a servir un populoso barrio obrero e industrial y 115 bibliotecas públicas, de las cuales 64 han sido creadas en los últimos dos años y que corresponden a Liceos, Escuelas Primarias, Municipios, Sindicatos obreros, etc.

Para esta tarea, la Biblioteca Nacional ha contado con cierta ayuda fiscal y con cuotas de Municipios y particulares. Mas, esos recursos son exiguos, nuestras fuerzas limitadas y la empresa grande y de inmensas proyecciones.

La Biblioteca Nacional aprovecha esta tribuna universitaria para formular un pedido en esta ceremonia de homenaje al libro: que los particulares, que las instituciones públicas y privadas, a semejanza de la ayuda que se dispensa a la Biblioteca Nacional de Buenos Aires, obsequien sus libros, revistas y diarios, ya leídos o sin mayor importancia, a la Biblioteca Nacional. Esos libros y revistas que generalmente estorban en las casas, en esos departamentos modernos de reducidas dimensiones, donde se arrumban y destruyen como cosas inútiles. Con ellos, desinfectados, encuadernados algunos, se podría abastecer a un sinnúmero de bibliotecas. Se podría acudir, también, a otros semejantes nuestros que, recluidos en Hospitales y Cárceles, carecen de tan preciado alimento espiritual.

El Acta de Fundación de la Biblioteca Nacional subscrita el 19 de agosto de 1813, dice a la letra: «El primer paso que dan los pueblos para ser sabios es proporcionarse grandes bibliotecas». Por esto el gobierno no omite gastos ni recursos para la Biblioteca Nacional, pero aun todavía no es esta Biblioteca digna del Pueblo que marcha protegido de la Providencia por todas las sendas de la gloria, y es también preciso que conozca todo el Mundo el interés que tiene cada Ciudadano en la beneficencia de los demás y que Chile compone una sola familia. Para esto se abre una subscripción patriótica de libros en donde cada uno, al ofrecer un objeto o dinero para su compra, puede decir con verdad: He aquí la parte con que contribuyo a la opinión y a la felicidad presente y futura de mi país. 